\title{
Fakultatywna podstawa odroczenia wykonania kary w kodyfikacji karnej z 1997 roku
}

\author{
Kamila MrozeK \\ ORCID: 0000-0001-7973-0281 \\ Katedra Prawa Karnego Wykonawczego \\ Wydział Prawa, Administracji i Ekonomii Uniwersytetu Wrocławskiego
}

Kodyfikacja karna z 1997 roku przyniosła wiele zmian w obrębie instytucji odroczenia wykonania kary ${ }^{1}$. Pod rządami kodeksu karnego wykonawczego z 1969 roku norma z art. 67 k.k.w. (obecnie art. 151 k.k.w.) stanowiła, że sąd może odroczyć wykonanie kary pozbawienia wolności na okres do 6 miesięcy, jeżeli przemawia za tym szczególny interes społeczny lub jeżeli natychmiastowe wykonanie kary pociągnęłoby dla skazanego lub jego rodziny zbyt ciężkie skutki².

Wprowadzone zmiany spowodowały znaczne rozbudowanie rozwiązań legislacyjnych skoncentrowanych wokół instytucji odroczenia wykonania kary, będąc przede wszystkim odpowiedzią na liczne wątpliwości zgłaszane przez praktykę, pojawiające się wraz z rozwojem przedmiotowej instytucji w obecnej kodyfikacji karnej, oraz próbą dostosowania jej do zmieniających się warunków społecznych.

${ }^{1}$ Ustawa z dnia 6 czerwca 1997 roku Kodeks karny wykonawczy (Dz.U. z 1997 r. Nr 90, poz. 557).

${ }^{2}$ Ustawa z dnia 19 kwietnia 1969 roku Kodeks karny wykonawczy (Dz.U. z 1969 r. Nr 13, poz. 98).

Nowa Kodyfikacja Prawa Karnego 54, 2019

(C) for this edition by CNS 
W pierwszej kolejności zwraca uwagę rezygnacja ustawodawcy z podstawy fakultatywnej określanej mianem „szczególnego interesu społecznego". Uznano bowiem, że pojęcie to w zmienionych warunkach ustrojowych i społeczno-ekonomicznych w Polsce straciło na znaczeniu, albowiem wcześniej ustawodawca $\mathrm{w}$ ten sposób chciał nie pozbawiać w określonym czasie państwowych zakładów pracy tak zwanych skazanych użytecznych ${ }^{3}$. Wśród okoliczności uzasadniających odroczenie na tej podstawie wskazywano między innymi: potrzebę umożliwienia skazanemu ukończenia pilnych prac lub znalezienia zastępcy do ich wykonania (na przykład zebranie plonów lub płodów rolnych), dobro zakładu pracy, gdy chodziło o wysoko wykwalifikowanego specjalistę, ułatwienie skazanemu zdania egzaminów lub ukończenia nauki ${ }^{4}$. Warto jednak dodać, że brak tej podstawy w obecnym art. 151 k.k.w. nie oznacza, że okoliczności te nie uzasadniają fakultatywnego odroczenia wykonania kary pozbawienia wolności, albowiem wpisują się w ramy „zbyt ciężkich skutków natychmiastowego wykonania kary".

Kodeks karny wykonawczy z dnia 6 czerwca 1997 roku wprowadził nieznaną dotąd fakultatywną podstawę odroczenia wykonania kary pozbawienia wolności z uwagi na „wystąpienie okoliczności, o której mowa w art. 248 k.k.w.”. Ratio legis przyjętego rozwiązania była zmiana zasad racjonalnej polityki penitencjarnej (przeciwdziałanie przeludnieniu) oraz wzgląd na obowiązek poszanowania zasady humanitaryzmu, nakazującej przestrzeganie normy, o której mowa w treści art. 110 k.k.w. ${ }^{5}$ $\mathrm{Z}$ art. $248 \S 2$ k.k.w. odsyłającego do aktu wykonawczego, to jest rozporządzenia Ministra Sprawiedliwości, wynikało jednoznacznie, że wa-

3 T. Szymanowski, Z. Świda, Kodeks karny wykonawczy. Komentarz. Ustawy dodatkowe. Akty wykonawcze, Warszawa 1998, s. 346.

4 S. Lelental, Prawo i polityka wykonywania kar, Łódź 1981, s. 163. Za szczególny interes społeczny uznawano również wzgląd na potrzebę obronności kraju, który wymagał odbycia przez żołnierzy zasadniczej służby wojskowej w sposób nieprzerwany w przypadku, gdy z powodu wymierzenia kary przekraczającej 6 miesięcy pozbawienia wolności nie miał zastosowania art. 301 k.k. z 1969 roku, a wymagania dyscypliny wojskowej nie przemawiały za koniecznością odizolowania skazanego od środowiska żołnierskiego (postanowienie Sądu Najwyższego z dnia 13 sierpnia 1979 roku, sygn. N 9/79, OSNKW 1979, nr 10, poz. 109).

5 T. Szymanowski, J. Migdał, Prawo karne wykonawcze i polityka penitencjarna, Warszawa 2014, s. 391.

Nowa Kodyfikacja Prawa Karnego 54, 2019

(C) for this edition by CNS 
runkiem odroczenia wykonania kary w trybie art. $151 \S 1$ k.k.w. była sytuacja, gdy liczba osadzonych w zakładach karnych lub aresztach śledczych przekraczała w skali kraju ogólną pojemność tych zakładów ${ }^{6}$. Gdyby jednak okazało się, że przeludnienie występuje w konkretnej jednostce, w której skazani mają odbywać orzeczoną karę pozbawienia wolności, dyrektor zakładu karnego lub aresztu śledczego mógł zdecydować o umieszczeniu osadzonych na czas określony w warunkach, w których powierzchnia w celi na jedną osobę wynosiła mniej niż $3 \mathrm{~m}^{2}$, zawiadamiając o tym bezzwłocznie sędziego penitencjarnego. A zatem jeżeli przeludnienie nie miało charakteru strukturalnego, należało stosować art. $248 \S 1$ k.k.w. ${ }^{7} \mathrm{~W}$ literaturze podkreślano, że wprowadzone rozwiązanie należy traktować jako jeden z mechanizmów postępowania wykonawczego, stanowiących zdecydowaną reakcję ustawodawcy na zjawisko przeludnienia występujące w polskich jednostkach penitencjarnych ${ }^{8}$.

Kodeks karny wykonawczy z 1997 roku kilkakrotnie zmieniał przedmiotową instytucję. Ustawą z dnia 9 października 2009 roku o zmianie ustawy - Kodeks karny wykonawczy ${ }^{9}$, na skutek wykonania wyroku Trybunału Konstytucyjnego z dnia 26 maja 2008 roku, sygn. akt SK 25/07, stwierdzającego niezgodność art. $248 \S 1$ k.k.w. z art. 40, 41 ust. 4 i art. 2 Konstytucji Rzeczypospolitej Polskiej, norma, o której mowa w art. 248 k.k.w., została uchylona, artykuł 151 k.k.w. zaś zyskał nowe brzmienie. Od tej pory sąd mógł odroczyć wykonanie kary pozbawienia wolności także wówczas, gdy liczba osadzonych w zakładach karnych lub aresztach śledczych przekraczała w skali kraju ogólną pojemność tych zakładów. Zastrzeżono również, że odroczenia na tej podstawie nie stosuje się wobec skazanego, który do-

${ }^{6}$ Rozporządzenie Ministra Sprawiedliwości z dnia 29 czerwca 1999 roku w sprawie zasad i trybu postępowania właściwych organów w wypadku, gdy liczba osadzonych w zakładach karnych lub aresztach śledczych przekroczy w skali kraju ogólną pojemność tych zakładów (Dz.U. z 1999 r. Nr 61, poz. 668 i 669). Przepisy rozporządzenia normowały obowiązki poszczególnych organów postępowania wykonawczego w wypadku stwierdzenia tak zwanego przeludnienia strukturalnego oraz przepływ informacji w tym przedmiocie.

${ }^{7}$ G. Wiciński, Postępowania incydentalne zwiąane z wykonaniem kary pozbawienia wolności w programie probacji, Łódź 2012, s. 138.

${ }^{8}$ K. Postulski, Kodeks karny wykonawczy. Komentarz, Warszawa 2012, s. 605.

${ }^{9}$ Ustawa z dnia 9 października 2009 roku o zmianie ustawy — Kodeks karny wykonawczy (Dz.U. Nr 190, poz. 1475).

Nowa Kodyfikacja Prawa Karnego 54, 2019

(C) for this edition by CNS 
puścił się przestępstwa z zastosowaniem przemocy lub groźby jej użycia lub orzeczono w stosunku do niego karę przekraczającą 2 lata pozbawienia wolności (art. $151 \S 1$ la k.k.w.).

W roku 2011 ustawodawca wprowadził dodatkowe ograniczenia stosowania odroczenia $\mathrm{z}$ uwagi na przeludnienie zakładów karnych ${ }^{10}$. Ustalony w 2009 roku katalog ograniczeń uzupełnił o skazanych, o których mowa w art. $64 \S 1$ lub 2 lub w art. 65 k.k., oraz skazanych za przestępstwa określone w art. 197-203 k.k. popełnione w związku z zaburzeniami preferencji seksualnych, podkreślając jednocześnie, iż propozycja ta adresowana jest do mniej zdemoralizowanych i niebezpiecznych przestępców. Uzasadnienia wprowadzonego rozwiązania należy poszukiwać w konieczności ograniczenia stosowania odroczenia z uwagi na tak zwane przeludnienie strukturalne tylko do przypadków drobniejszych przestępstw oraz mniej zdemoralizowanych i niebezpiecznych sprawców ${ }^{11}$.

Ostatnia zmiana wprowadzona ustawą z dnia 20 lutego 2015 roku o zmianie ustawy - Kodeks karny wykonawczy oraz niektórych innych ustaw $^{12}$ zlimitowała wymiar kary pozbawienia wolności podlegającej odroczeniu z przyczyn systemowych z 2 lat do roku. Związane to było z nowelą art. $69 \S 1$ k.k., który to od 2015 roku ograniczył możliwość warunkowego zawieszenia wykonania kary tylko do przypadków, kiedy kara pozbawienia wolności nie przekracza roku.

Trudno było bowiem znaleźć uzasadnienie istniejącego dysonansu między art. $69 \S 1$ k.k. a art. $152 \S 1$ k.k.w. Odpowiedniej zmiany wymagał zatem również art. $151 \S 2$ k.k.w. Jakkolwiek w tym ostatnim mowa nie o warunkowym zawieszeniu, lecz o odroczeniu wykonania kary pozbawienia wolności, to jednak oba są z sobą funkcjonalnie powiązane, a granica wymiaru kary określona w art. $151 \S 2$ k.k.w., pozwalająca na odroczenie, nie powinna różnić się od wskazanej w art. 69 § 1 k.k. ${ }^{13}$

Ustawą z dnia 16 września 2011 roku o zmianie ustawy — Kodeks karny wykonawczy oraz niektórych innych ustaw wydłużono okres jed-

10 Ustawa z dnia 16 września 2011 roku o zmianie ustawy — Kodeks karny wykonawczy oraz niektórych innych ustaw (Dz.U. Nr 240, poz. 1431).

11 Uzasadnienie projektu ustawy o zmianie ustawy - Kodeks karny wykonawczy oraz niektórych innych ustaw z dnia 9 marca 2011 roku, druk nr 3961.

12 Ustawa z dnia 20 lutego 2015 roku o zmianie ustawy - Kodeks karny oraz niektórych innych ustaw (Dz.U. z 2015 r. poz. 396).

13 K. Mrozek, Odroczenie wykonania kary, Wrocław 2019, s. 103.

Nowa Kodyfikacja Prawa Karnego 54, 2019

(C) for this edition by CNS 
norazowego odroczenia wykonania kary pozbawienia wolności z 6 miesięcy do 1 roku. Odroczenie mogło być bowiem udzielane kilkakrotnie, jednakże co do zasady łączny okres odroczenia nie mógł przekroczyć roku. Na marginesie należy wspomnieć, że nowelizacja ta przyniosła najwięcej zmian na gruncie instytucji odroczenia wykonania kary pozbawienia wolności, istotnie zmieniając podstawę fakultatywną. W uzasadnieniu do projektu wskazano, że

rezygnacja z zapisu „do 6 miesięcy” ma na celu wyeliminowanie kilkakrotnego orzekania w przedmiocie odroczenia wykonania kary w przypadkach, kiedy z ustaleń sądu wynika, że konieczne jest orzeczenie o odroczeniu na dłuższy okres niż 6 miesięcy ${ }^{14}$.

Nowela ta usunęła również pojawiające się dotychczas wątpliwości w zakresie sposobu obliczania okresu odroczenia w przypadku wydania postanowienia o dalszym stosowaniu przedmiotowej instytucji. Początkowo zakładano, że okres odroczenia biegnie od dnia wydania postanowienia w tym przedmiocie ${ }^{15}$. Rozwiązanie to rodziło komplikacje w sytuacji, gdy kolejne postanowienia były wydawane po upływie okresu wyznaczonego w pierwszym postanowieniu bądź nawet przed jego upływem. Także orzecznictwo, w tym Sądu Najwyższego, nie rozstrzygało jednoznacznie problemu, jak w przypadku złożenia kolejnego wniosku o odroczenie wykonania kary na dalszy okres należy traktować czas między upływem terminu pierwszego odroczenia a datą wydania kolejnego postanowienia o dalszym jej odroczeniu i jaki wpływ ma ten okres na bieg rocznego terminu odroczenia, zwłaszcza w kontekście warunkowego zawieszenia wykonania kary w trybie art. 152 k.k.w. ${ }^{16}$ Wątpliwości te rozstrzygnęła ostatecznie uchwała Sądu Najwyższego z dnia 25 lutego 2009 roku, w której wyjaśniono, że

do łącznego okresu odroczenia wykonania kary pozbawienia wolności, określonego w treści art. $151 \S 3 \mathrm{KKW}$, stwarzającego możliwość ubiegania się o warunkowe zawieszenie wykonania kary pozbawienia wolności na podstawie art. $152 \mathrm{KKW}$, okres pomiędzy datą zakończenia wcześniej udzielonego odroczenia a datą kolejnego postanowienia

14 Uzasadnienie projektu ustawy o zmianie ustawy...

15 Warto pamiętać, że Z. Hołda i K. Postulski już w roku 1998 wskazywali, pomimo braku stosownej regulacji w ustawie, że „końcowa data udzielanych parokrotnie odroczeń wykonania kary na podstawie art. $151 \S 1$ nie może wykraczać poza okres roku, liczony od dnia wydania pierwszego postanowienia o odroczeniu", zob. Z. Hołda, K. Postulski, Kodeks karny wykonawczy. Komentarz, Gdańsk 1998, s. 334.

16 K. Postulski, Kodeks karny wykonawczy. Komentarz, Warszawa 2017, s. 718.

Nowa Kodyfikacja Prawa Karnego 54, 2019

(C) for this edition by CNS 
o odroczeniu, wlicza się tylko wówczas, gdy wniosek o kolejne odroczenie został złożony przed zakończeniem wcześniej udzielonego okresu odroczenia, przy czym łączny okres udzielonego kilkakrotnie odroczenia nie może, w żadnej sytuacji, przekroczyć roku od dnia wydania pierwszego postanowienia o odroczeniu, chyba że chodzi o kobietę ciężarną lub w okresie 3 lat po urodzeniu dziecka lub sprawowania nad nim opieki.

Uchwała ta, mająca moc zasady prawnej, wyeliminowała powyższe wątpliwości, a sam przepis art. $151 \S 3 \mathrm{k} . \mathrm{k} . w$. stał się czytelny nie tylko dla sądów, ale przede wszystkim samych skazanych.

Ciąża skazanej i fakt sprawowania opieki nad dzieckiem do lat 3 po jego urodzeniu nie zostały wprost wyartykułowane przez ustawodawcę w ustawie z 1969 roku jako okoliczności uzasadniające odroczenie wykonania kary pozbawienia wolności. Niemniej już w tym czasie określano je mianem szczególnego problemu, który w imię zasady ochrony macierzyństwa i zasady humanitaryzmu racjonalizował udzielenie odroczenia wykonania kar ${ }^{17}$. Kodeks karny wykonawczy z 1997 roku doprowadził do prawnego uprzywilejowania skazanych kobiet ciężarnych i matek sprawujących opiekę nad dziećmi, poprzez wydłużenie okresu odroczenia wykonania kary pozbawienia wolności ponad ustawowy rok. Przepis ten przewidywał odstępstwo o charakterze podmiotowym od zasady głoszącej, że okres odroczenia wykonania kary nie mógł przekroczyć roku. Maksymalny czas odroczenia wykonania kary w takim wypadku nie mógł trwać dłużej niż okres ciąży, z powodu której nastąpiło odroczenie, a następnie przez 3 lata po urodzeniu dziecka.

Początkowo możliwość orzekania o odroczeniu na tej podstawie wynikała z normy poświęconej ograniczeniom czasowym stosowania przedmiotowej instytucji. Dopiero w wyniku zmiany wprowadzonej do ustawy w 2012 roku okoliczność ta zyskała rangę samodzielnej podstawy oprócz sytuacji, gdy natychmiastowe wykonanie kary pociągnęłoby dla skazanego lub jego rodziny zbyt ciężkie skutki oraz gdy liczba osadzonych w zakładach karnych lub aresztach śledczych przekroczy w skali kraju ogólną pojemność tych zakładów. Nowela ta doprecyzowała także zakres podmiotowy uprawniający do skorzystania z omawianej podstawy. Dotychczas przepis wskazywał wyraźnie, że podmiotem tego postępowania może być wyłącznie kobieta ciężarna lub sprawująca opiekę nad dzieckiem do lat 3 po jego urodzeniu. Po zmianie z 2012 roku

17 S. Lelental, Prawo karne wykonawcze, Warszawa 1990, s. 139.

Nowa Kodyfikacja Prawa Karnego 54, 2019

(C) for this edition by CNS 
z odroczenia może skorzystać też inna osoba niż matka, sprawująca osobiście opiekę nad dzieckiem. Przepis ten w obecnym brzmieniu poszerza zakres upodmiotowienia mężczyzny na gruncie rodzicielstwa w polskim systemie prawa, zrównując tym samym pozycję ojca i matki w kontekście odroczenia wykonania kary pozbawienia wolności. W tym zakresie prawa ojca zasadniczo odpowiadają prawom matki i wpisują się w cele społeczne funkcjonowania rodziny ${ }^{18}$. Warto zaznaczyć, że z odroczenia na tej podstawie mogą korzystać nie tylko skazani rodzice, lecz także każda inna osoba, pod warunkiem że wykaże fakt sprawowania opieki oraz okoliczność, że opieki tej nie mogą zapewnić inne osoby.

Nowelizacja z 2012 roku wprowadziła dodatkowo fakultatywną możliwość nałożenia na skazanego określonych obowiązków. Z treści art. $151 \S 4$ k.k.w. wynika wprost, że odraczając wykonanie kary pozbawienia wolności, sąd może zobowiązać skazanego do podjęcia starań o znalezienie pracy zarobkowej, zgłaszania się do wskazanej jednostki Policji w określonych odstępach czasu lub poddania się odpowiedniemu leczeniu lub rehabilitacji, oddziaływaniom terapeutycznym lub uczestnictwu w programach korekcyjno-edukacyjnych. Zastosowanie alternatywy „lub” oznacza, że sąd może nałożyć na skazanego jeden obowiązek, niektóre z nich lub wszystkie jednocześnie. Zasadność, a także wybór określonego obowiązku powinien wynikać z właściwości osobistych skazanego, warunków środowiskowych, w jakich będzie przebywał w okresie odroczenia wykonania kary, jak też deklarowanego celu, jakiemu ma ono służyć.

Wprowadzenie możliwości nałożenia na skazanego wymienionych obowiązków spowodowało konieczność wdrożenia przepisu, który pełniłby funkcję kontrolną w zakresie ich przestrzegania. Od dnia 1 stycznia 2012 roku odpowiednie zastosowanie art. 14 k.k.w. pozwala na prowadzenie kontroli przebiegu postępowania wykonawczego i wykonania nałożonych przez sąd obowiązków w sprawach dotyczących między innymi odroczenia wykonania kary pozbawienia wolności, co wynika wprost z treści art. $151 \S 5$ k.k.w. Warto dodać, że regulacja ta znajduje zastosowanie również przy przerwie w karze, przy możliwości nałożenia analogicznych obowiązków. W uzasadnieniu do projektu podnoszono,

18 Szerzej K. Mrozek, op. cit., s. 92.

Nowa Kodyfikacja Prawa Karnego 54, 2019

(C) for this edition by CNS 
że w katalogu tym powinien znaleźć się także obowiązek skazanego do utrzymywania w czasie odroczenia kontaktu z sądowym kuratorem zawodowym, co nie tylko wpłynie na jakość kontroli sądu nad skazanym w okresie odroczenia, ale też zmotywuje skazanych do właściwego zachowania. Tym bardziej że rozwiązanie to stosowane było dotąd przy przerwie w karze (art. 153 § 4 k.k.w. w brzmieniu do 1 stycznia 2012 roku). Niemniej z niezrozumiałych względów ustawodawca, tworząc katalog obowiązków fakultatywnych mających zastosowanie zarówno przy odroczeniu, jak i przy przerwie, zrezygnował całkowicie z konieczności utrzymywania kontaktu z sądowym kuratorem zawodowym.

Analiza podstaw fakultatywnego odroczenia wykonania kary pozbawienia wolności uprawnia do stwierdzenia, iż pod rządami obecnie obowiązującego kodeksu karnego wykonawczego instytucja ta istotnie ewaluowała. W porównaniu z regulacją przewidzianą w art. 67 poprzedniej ustawy śmiało można stwierdzić, że stała się ona środkiem dojrzałym, będącym odpowiedzią na liczne postulaty pojawiające się w praktyce jej stosowania. Obecny jej kształt stanowi o poszanowaniu zasady humanitaryzmu oraz indywidualizacji wykonania kary pozbawienia wolności. Może być ponadto panaceum dla stosunkowo szerokiej grupy skazanych, co jest możliwe dzięki rozbudowaniu w ciągu ostatnich 20 lat katalogu przesłanek fakultatywnych jej stosowania. Z entuzjazmem należy również przyjąć uprzywilejowanie przez ustawodawcę kobiet ciężarnych oraz osób sprawujących opiekę nad dziećmi do lat 3 po ich urodzeniu. Ponadto wprowadzenie do ustawy obowiązków, które mogą niejako uzupełniać postanowienie o odroczeniu wykonania kary w połączeniu z możliwością kontroli ich wykonywania przez kuratorów sądowych, wzmacnia pozycję przedmiotowej instytucji na tle innych postępowań incydentalnych, albowiem stwarza realną możliwość rozpoczęcia procesu resocjalizacji jeszcze w warunkach wolnościowych.

Należy jednak postulować wprowadzenie do katalogu z art. 151 $\S 4$ k.k.w. obowiązku skazanego do utrzymywania w czasie odroczenia kontaktu z sądowym kuratorem zawodowym, co — jak już podnoszono - zmotywuje skazanych do właściwego zachowania w czasie odroczenia wykonania kary pozbawienia wolności. Nie bez znaczenia pozostaje odroczenie wykonania kary w walce ze zjawiskiem przeludnienia w polskich jednostkach penitencjarnych. Ustawodawca dostrzegł bowiem po-

Nowa Kodyfikacja Prawa Karnego 54, 2019

(C) for this edition by CNS 
tencjał tej instytucji, tworząc w ten sposób kolejny instrument mający realny wpływ na redukcję populacji osób pozbawionych wolności. W tym kontekście nie można zatem przejść obojętnie obok zmiany wprowadzonej ustawą z dnia 19 lipca 2019 roku o zmianie ustawy - Kodeks postępowania karnego oraz niektórych innych ustaw ${ }^{19}$, która uchyla możliwość stosowania w postępowaniu wykonawczym art. 152. Skoro zatem ustawodawca rezygnuje z warunkowego zawieszenia wykonania kary, należy poddać pod rozwagę sens pozostawienia w ustawie możliwości odroczenia wykonania kary z przyczyn systemowych. Wydaje się bowiem, że oba te przepisy były wzajemnie powiązane, a istotą odroczenia wykonania kary w trybie art. $151 \S 2$ k.k.w. nie było chwilowe przesunięcie w czasie rozpoczęcia wykonania kary, lecz skorzystanie z dobrodziejstwa oferowanego przez ustawodawcę właśnie w art. 152 k.k.w.

\section{Bibliografia}

Hołda Z., Postulski K., Kodeks karny wykonawczy. Komentarz, Gdańsk 1998.

Lelental S., Prawo i polityka wykonywania kar, Łódź 1981.

Lelental S., Prawo karne wykonawcze, Warszawa 1990.

Mrozek K., Odroczenie wykonania kary, Wrocław 2019.

Postulski K., Kodeks karny wykonawczy. Komentarz, Warszawa 2012.

Postulski K., Kodeks karny wykonawczy. Komentarz, Warszawa 2017.

Szymanowski T., Świda Z., Kodeks karny wykonawczy. Komentarz. Ustawy dodatkowe. Akty wykonawcze, Warszawa 1998.

Szymanowski T., Migdał J., Prawo karne wykonawcze i polityka penitencjarna, Warszawa 2014.

Wiciński G., Postepowania incydentalne zwiąane z wykonaniem kary pozbawienia wolności w programie probacji, Łódź 2012.

\section{Akty prawne}

Rozporządzenie Ministra Sprawiedliwości z dnia 29 czerwca 1999 roku w sprawie zasad i trybu postępowania właściwych organów w wypadku, gdy liczba osadzonych w zakładach karnych lub aresztach śledczych przekroczy w skali kraju ogólną pojemność tych zakładów (Dz.U. z 1999 r. Nr 61, poz. 668 i 669).

19 Ustawa z dnia 19 lipca 2019 roku o zmianie ustawy - Kodeks postępowania karnego oraz niektórych innych ustaw (Dz.U z 2019 r. poz. 1694).

Nowa Kodyfikacja Prawa Karnego 54, 2019

(C) for this edition by CNS 
Ustawa z dnia 19 kwietnia 1969 roku Kodeks karny wykonawczy (Dz.U. z 1969 r. Nr 13, poz. 98$)$.

Ustawa z dnia 6 czerwca 1997 roku Kodeks karny wykonawczy (Dz.U. z 1997 r. Nr 90, poz. 557).

Ustawa z dnia 9 października 2009 roku o zmianie ustawy — Kodeks karny wykonawczy (Dz.U. Nr 190, poz. 1475).

Ustawa z dnia 16 września 2011 roku o zmianie ustawy — Kodeks karny wykonawczy oraz niektórych innych ustaw (Dz.U. Nr 240, poz. 1431).

Ustawa z dnia 20 lutego 2015 roku o zmianie ustawy — Kodeks karny oraz niektórych innych ustaw (Dz.U. z 2015 r. poz. 396).

Ustawa z dnia 19 lipca 2019 roku o zmianie ustawy - Kodeks postępowania karnego oraz niektórych innych ustaw (Dz.U. z 2019 r. poz. 1694).

\section{Orzecznictwo}

Postanowienie Sądu Najwyższego z dnia 13 sierpnia 1979 roku, sygn. N 9/79, OSNKW 1979, nr 10, poz. 109.

\section{Inne}

Uzasadnienie projektu ustawy o zmianie ustawy — Kodeks karny wykonawczy oraz niektórych innych ustaw z dnia 9 marca 2011 roku, druk nr 3961.

\section{Optional basis for postponement of sentence in the 1997 criminal codification}

\section{Summary}

The study contains a synthetic analysis of the optional basis for postponing the execution of a custodial sentence. Considerations began with recalling the shape of the institution under the previous codification. Then, all the amendments pursuant to Art. 151 of the Executive Penal Code made under the current law were analysed. Particular attention was paid to changes devoted to the legal privileges of pregnant women and persons taking care of children up to 3 years after birth and postponing the execution of the sentence for systemic reasons, completely independent of the convict, and related to overcrowding in Polish penitentiary units.

Keywords: postponement of punishment, overcrowding, community interview, professional court probation officer. 